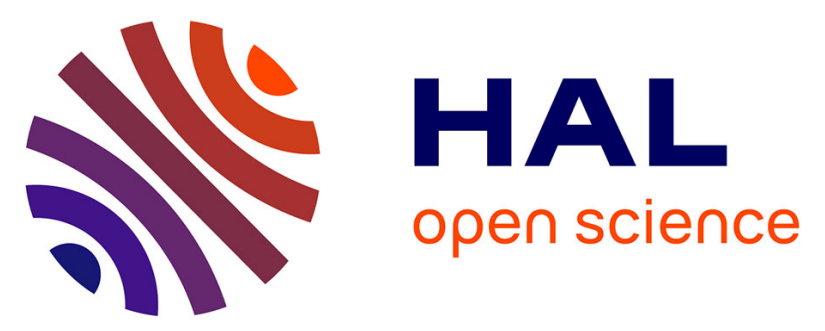

\title{
Gambierol Potently Increases Evoked Quantal Transmitter Release and Reverses Pre- and Post-Synaptic Blockade at Vertebrate Neuromuscular Junctions
}

Jordi Molgó, Sébastien Schlumberger, Makoto Sasaki, Haruhiko Fuwa, Carmen M. Louzao, Luis M. Botana, Denis Servent, Evelyne Benoit

\section{To cite this version:}

Jordi Molgó, Sébastien Schlumberger, Makoto Sasaki, Haruhiko Fuwa, Carmen M. Louzao, et al.. Gambierol Potently Increases Evoked Quantal Transmitter Release and Reverses Pre- and PostSynaptic Blockade at Vertebrate Neuromuscular Junctions. Neuroscience, 2020, 439, pp.106-116. 10.1016/j.neuroscience.2019.06.024 . hal-02324830

\section{HAL Id: hal-02324830 \\ https://hal.science/hal-02324830}

Submitted on 21 May 2020

HAL is a multi-disciplinary open access archive for the deposit and dissemination of scientific research documents, whether they are published or not. The documents may come from teaching and research institutions in France or abroad, or from public or private research centers.
L'archive ouverte pluridisciplinaire HAL, est destinée au dépôt et à la diffusion de documents scientifiques de niveau recherche, publiés ou non, émanant des établissements d'enseignement et de recherche français ou étrangers, des laboratoires publics ou privés. 


\title{
Gambierol potently increases evoked quantal transmitter release and reverses pre-and post-synaptic blockade at vertebrate neuromuscular junctions *
}

\author{
Jordi Molgó $^{\text {a,b** }}$, Sébastien Schlumberger $^{\text {b }}$, Makoto Sasaki ${ }^{\text {c }}$, Haruhiko Fuwa ${ }^{\text {d }}$, M.
}

Carmen Louzao $^{\text {e }}$, Luis M. Botana ${ }^{\text {e }}$, Denis Servent ${ }^{\text {a }}$, Evelyne Benoit ${ }^{\text {a,b }}$

${ }^{a}$ CEA, Institut des sciences du vivant Frédéric Joliot, Service d'Ingénierie Moléculaire des

Protéines, Université Paris-Saclay, bâtiment 152, 91191 Gif sur Yvette, France;

${ }^{b}$ Institut des Neurosciences Paris-Saclay, UMR 9197 CNRS / Université Paris-Sud, CNRS, Gif sur Yvette, France;

${ }^{c}$ Graduate School of Life Sciences, Tohoku University, Sendai, Japan;

${ }^{d}$ Department of Applied Chemistry, Faculty of Science and Engineering, Chuo University 1-1327 Kasuga, Bunkyo, Tokyo 112-8551, Japan

${ }^{e}$ Departamento de Farmacología, Facultad de Veterinaria, Universidad de Santiago de Compostela, Lugo, Spain.

* This article is dedicated to honor the memory of Professor Ricardo Miledi, which one of us (J.M.) met for the first time in 1974 in Gif sur Yvette, for his human qualities and sincere friendship. During the many years of scientific inquiry of the highest quality, Ricardo has made important contributions to our understanding of the physiology and pharmacology of the vertebrate neuromuscular junction. His dedication to research has been an inspiration to us all. *** corresponding author's email: jordi.molgo@cea.fr ～ORCID iD: 0000-0002-0693-8994

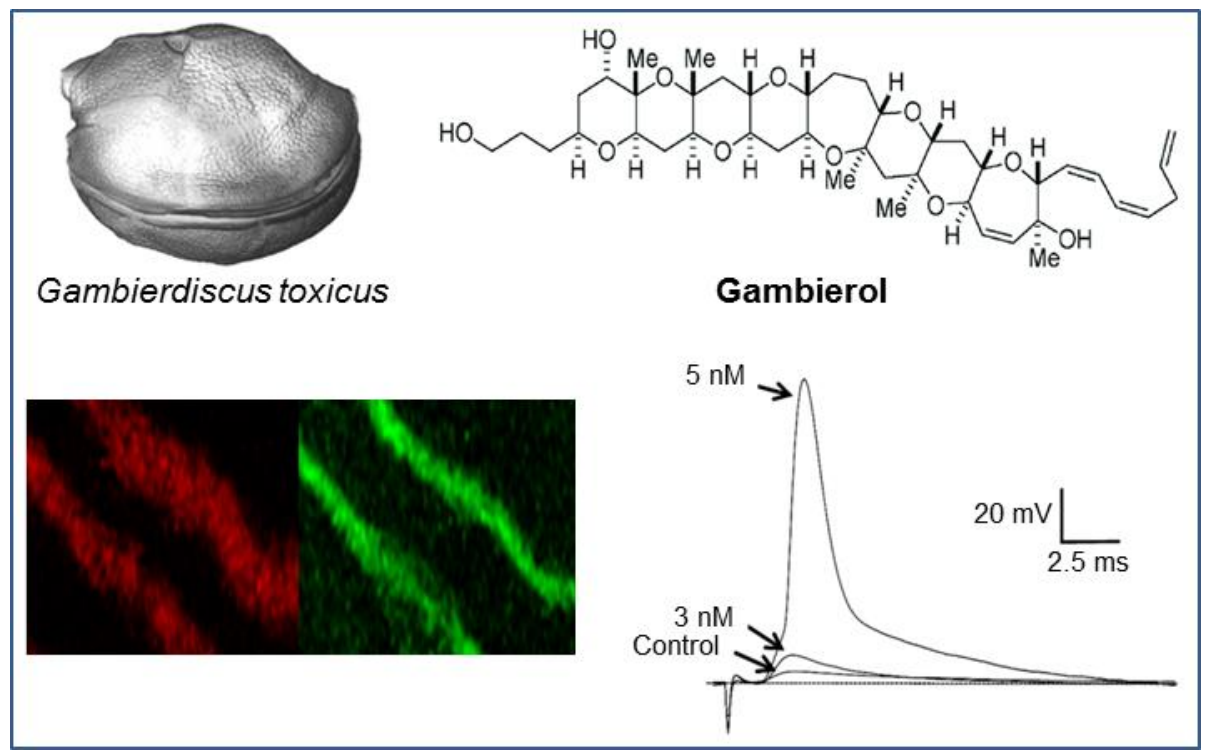




\title{
Highlights
}

- The synthetic polyether toxin gambierol potently enhanced stimulus-evoked quantal transmitter release.

- The presynaptic fast K+ current was inhibited and the synaptic delay prolonged by gambierol.

- Gambierol reversed the postsynaptic block produced by d-tubocurarine.

- Gambierol restored from complete paralysis neuromuscular transmission ex vivo in BoNT/Apoisoned mouse muscle.

- Gambierol increased the transient $\mathrm{Ca} 2+$ signals in nerve terminals stimulated at 1 and $10 \mathrm{~Hz}$.

\begin{abstract}
Abbreviations
BoNT/A, botulinum neurotoxin type A

3,4-DAP, 3,4-diaminopyridine

EPP, endplate potential

mEPP, miniature endplate potential

DAS, Digit Abduction Scoring;

EDL, extensor digitorum longus;

LAL, levator aurus longus;

SNAP-25, synaptosomal-associated protein of $25 \mathrm{kDa}$;

SNARE, soluble soluble N-ethylmaleimide-sensitive factor attachment protein receptor; $\alpha$-BgTx, $\alpha$-Bungarotoxin
\end{abstract}

\begin{abstract}
Gambierol is a marine polycyclic ether toxin, first isolated from cultured Gambierdiscus toxicus dinoflagellates collected in French Polynesia. The chemical synthesis of gambierol permitted the analyses of its mode of action which includes the selective inhibition of voltage-gated $\mathrm{K}^{+}\left(\mathrm{K}_{\mathrm{V}}\right)$ channels. In the present study we investigated the action of synthetic gambierol at vertebrate neuromuscular junctions using conventional techniques. Gambierol was studied on neuromuscular junctions in which muscle nicotinic ACh receptors have been blocked with d-tubocurarine (postsynaptic block), or in junctions in which quantal ACh release has been greatly reduced by a low $\mathrm{Ca}^{2+}$-high $\mathrm{Mg}^{2+}$ medium or by botulinum neurotoxin type-A (BoNT/A) (presynaptic block). Results show that nanomolar concentrations of gambierol inhibited the fast $\mathrm{K}^{+}$current and prolonged the duration of the presynaptic action potential in motor nerve terminals, as revealed by presynaptic focal current recordings, increased stimulus-evoked quantal content in junctions blocked by high $\mathrm{Mg}^{2+}$-low $\mathrm{Ca}^{2+}$ medium, and by BoNT/A, reversed the postsynaptic block produced by $\mathrm{d}$ tubocurarine and increased the transient $\mathrm{Ca}^{2+}$ signals in response to nerve-stimulation $(1-10 \mathrm{~Hz})$ in nerve terminals loaded with fluo-3/AM. The results suggest that gambierol, which on equimolar basis is more potent than 3,4-diaminopyridine, can have potential application in pathologies in which it is necessary to antagonize pre- or post-synaptic neuromuscular block, or both.
\end{abstract}

Keywords: Gambierol, marine biotoxin, nerve terminal, quantal transmitter release, potassium current, botulinum type A neurotoxin, $\mathrm{Ca}^{2+}$ transients 


\section{Introduction}

Biologically-active natural products and toxins from terrestrial and marine origin not only exhibit a great chemical diversity, but also constitute an important and rich source of new drug leads and drug candidates. Most of the marine polycyclic ether natural products are recognized secondary metabolites of dinoflagellates (Yasumoto, 2001). The wide-range and chemical diversity among marine toxins has attracted significant consideration among synthetic organic chemists which have produced large and complex molecules facilitating the investigation of their mode of mode of action (Nicolaou et al., 2008; Mori, 2019).

Gambierol is a marine polycyclic ether toxin (Fig. 1) that was first isolated and chemically characterized from cultured Gambierdiscus toxicus dinoflagellates isolated in French Polynesia (Satake et al., 1993). The genus Gambierdiscus is known to produce a number of ladder cyclic compounds known as ciguatoxins, that are responsible for ciguatera fish poisoning, a foodborne disease caused by the consumption of marine fishes (from tropical or temperate waters) contaminated with ciguatoxins (Larsson et al., 2018), or ciguatera-like poisoning events resulting from the consumption of marine invertebrates (giant clams or sea urchins) containing ciguatoxins (Darius et al., 2018). Despite the chemical complexity of polycyclic ether toxins, the total synthesis of gambierol and analogues has been accomplished using different chemical strategies (Alonso et al., 2012; Furuta et al., 2009; Johnson et al., 2005; Fuwa et al., 2002) which permitted the detailed analyses of their mode of action. As shown in Fig. 1, gambierol is characterized by a transfused octacyclic polyether core containing 18 stereogenic centers and a partially skipped triene side chain including a conjugated (Z,Z)-diene system.

Fig. 1. Near here

Gambierol and analog synthetic compounds in nanomolar concentrations have been reported to inhibit voltage-gated $\mathrm{K}^{+}(\mathrm{Kv})$ channels in various cells and tissues including mouse taste cells (Ghiaroni et al., 2005), Xenopus skeletal myocytes (Schlumberger et al., 2010), murine cerebellar neurons (Pérez et al., 2012), mammalian Kv1.1-Kv1.5 channels expressed in Xenopus oocytes or in Chinese hamster ovary (CHO) cells (Cuypers et al., 2008; Konoki et al., 2015), Kv3.1 channels expressed in mouse fibroblasts (Kopljar et al., 2009), and human Kv1.3 channels from T-lymphocytes (Rubiolo et al., 2015). In the range of nanomolar concentrations affecting $\mathrm{Kv}$ channels, gambierol has previously been reported to not affect or block voltage-gated $\mathrm{Na}^{+}$channels (Ghiaroni et al., 2005; Cuypers et al., 2008; Schlumberger et al., 2010; Pérez et al., 2012).

The aim of the present study was (i) to investigate whether the synthetic polyether toxin gambierol had an action on spontaneous and evoked quantal transmitter release at frog and mammalian neuromuscular junctions, (ii) to determine if the presynaptic $\mathrm{K}^{+}$current in motor nerve terminals was sensitive to the polyether toxin, and if changes in the synaptic delay could be detected, (iii) to disclose if gambierol could antagonize the postsynaptic block produced by dtubocurarine, (iv) to find out if gambierol could have an action on junctions poisoned by botulinum 
neurotoxin type-A (BoNT/A) in which neurotransmitter release has been greatly reduced, and (v) to determine if $\mathrm{Ca}^{2+}$ transients were modified by the polyether toxin.

A preliminary account on a part of this work has been communicated by J.M. at the $18^{\text {th }}$ International Conference on Harmful Algae (21-26 October) in Nantes, France.

\section{Experimental Procedures}

Chemicals, solutions and toxins

Gambierol with purity of $>97 \%$ was produced by chemical synthesis, as previously reported (Fuwa et al., 2002). Synthetic gambierol, identical to natural gambierol, was dissolved in dimethyl sulfoxide (DMSO) and then diluted in the physiological solution. The total DMSO concentration in solutions did not exceed $0.1 \%$. Fluo 3-AM was dissolved in $0.02 \%$ DMSO containing $0.01 \%$ pluronic acid F-127 (Molecular Probes), both compound were purchased from Invitrogen (Villebon sur Yvette, France). Isoflurane (Aerrane®) anesthetic was from Baxter S.A., Lessines, Belgium. D-tubocurarine chloride was purchased from Tocris Bioscience (Bristol, UK). All chemicals, including 3,4-diaminopyridine (3,4-DAP), and formamide were purchased from

Sigma-Aldrich (Saint Quentin Fallavier, France; The $\mu$-conotoxin GIIIB, and tetrodotoxin were obtained from Alomone Labs (Alomone Labs, Jerusalem, Israel). $\alpha$-Bungarotoxin Alexa Fluor ${ }^{\mathrm{TM}}$ 594 conjugate was from Invitrogen. Botulinum neurotoxin type A1 (BoNT/A) was a kind gift from Professor Michel Popoff (Pasteur Institute, Paris).

\section{Animals}

Adult male Swiss mice (Mus musculus, 2-3 months of age and 23-28 g of body weight) were purchased from Janvier Elevage (Le Genest-Saint-Isle, France), and acclimatized at the animal facility for at least $72 \mathrm{~h}$ before experiments. Live animals were treated according to the European Community guidelines for laboratory animal handling and to the guidelines established by the French Council on animal care "Guide for the Care and Use of Laboratory Animals" (EEC86/609 Council Directive - Decree 2001-131). In particular, they were housed in groups of four- to six in cages with environmental enrichment, in a room with constant temperature and a standard light cycle (12-h light/12-h darkness), and had water and food ad libitum. All experimental procedures on mice were approved by the Animal Ethics Committee of the CEA (project 17_088 authorized to E.B.) and by the French General Directorate for Research and Innovation (project APAFIS\#26712015110915123958v4 authorized to E.B.). Rana esculenta frogs (20-25 g body weight) were bred and maintained in a natural water pond of the CNRS campus in Gif Sur Yvette, and used during the months of September-October. All efforts were made to minimize the number of animals used and their suffering.

\section{BoNT/A in vivo injection}

Swiss mice anaesthetized with isoflurane inhalation were injected with a single intramuscular 
injection of $30 \mu \mathrm{L}$ containing $10 \mathrm{pg}$ BoNT/A/ mouse (based on $150 \mathrm{kDa}$ BoNT/A neurotoxin protein) into the anterolateral region of the left hind limb into the mid-point of the Tibialis anterior muscle. Control animals received a single injection of $30 \mu \mathrm{L}$ of the vehicle used to dilute the neurotoxin. Mice were evaluated in vivo for eventual paralysis using the Digit Abduction Score (DAS) assay $72 \mathrm{~h}$ post-neurotoxin injection. The DAS response was scored with the animal facing up in a reclining position. The digit-abduction was scored on a five points scale in which 0 $=$ normal and $4=$ maximal reduction in digit abduction (Aoki, 2001). Mice were sacrificed $72 \mathrm{~h}$ post-BoNT/A or -vehicle injection.

Isolated nerve-muscle preparations

Mice were anesthetized with isoflurane inhalation before being euthanized by dislocation of cervical vertebrae followed by immediate exsanguinations. Mouse phrenic-nerve-hemidiaphragm-muscle preparations, peroneal nerve-extensor digitorum longus (EDL) muscle), or levator auris longus nerve-muscle preparation were isolated, and mounted in a silicone-lined Plexiglass ${ }^{\circledR}$ chamber $(2 \mathrm{~mL}$ volume) superfused with an oxygenated standard Krebs-Ringer solution of the following composition (in $\mathrm{mM}$ ): $\mathrm{NaCl} \mathrm{140,} \mathrm{KCl} 5, \mathrm{CaCl}_{2} 2, \mathrm{MgCl}_{2}$ 1, D-glucose 11, and HEPES 5 ( $\mathrm{pH}$ 7.4) In some experiments, the $\mathrm{CaCl}_{2}$ was reduced to $0.4 \mathrm{mM}$ and $\mathrm{MgCl}_{2}$ was increased to $8.0 \mathrm{mM}$, the osmolarity being kept constant. In some experiments nerve-muscle preparations were incubated with $\mu$-conotoxin GIIIB (1.0-1.6 $\mu \mathrm{M})$, which blocks specifically and irreversibly voltage-gated muscle $\mathrm{Na}^{+}$channels (Cruz et al., 1985) and, thus, inhibits muscle contraction upon nerve stimulation.

Frog Cutaneous pectoris nerve-muscle preparations were removed from frogs euthanized by double pithing. Each isolated preparation was pinned in a silicone-lined two-compartment Plexiglass $®$ chamber ( $2 \mathrm{~mL}$ volume) and bathed in a standard frog physiological solution composed of (in $\mathrm{mM}$ ): $115 \mathrm{NaCl}, 2 \mathrm{KCl}, 1.8 \mathrm{CaCl}_{2}$, and $5 \mathrm{HEPES}$ (buffered at $\mathrm{pH}$ 7.25). Some experiments were performed on muscles in which excitation-contraction coupling was eliminated by pre-treatment with $2 \mathrm{M}$ formamide (Del Castillo and Escalona de Motta, 1978) for 18-20 min, followed by abundant washing with standard frog solution at $4{ }^{\circ} \mathrm{C}$, and allowing gradual increase in temperature and 60-90 min for recovery of the muscle membrane potential.

\section{Electrophysiological recordings}

Fire-polished glass microelectrodes (filled with standard saline and having resistance of 1-2 M $\Omega$ ) and an Axoclamp-2A system (Axon Instruments, Union City, CA, USA) were used to record presynaptic currents from motor nerve terminals of the levator auris longus (LAL) nerve-muscle preparation (Angaut-Petit et al., 1987). An $\mathrm{Ag}-\mathrm{AgCl}$ pellet located in the bath served as the reference electrode.

Intracellular recordings of the resting membrane potential, end-plate potential (EPP) and miniature end-plate potential (mEPP) were made with standard techniques, using an Axoclamp$2 \mathrm{~A}$ system and glass microelectrodes filled with $3 \mathrm{M} \mathrm{KCl}$ and resistances of 10-12 $\mathrm{M} \Omega$. The 
motor nerve was stimulated through a suction microelectrode (adapted to the diameter of the nerve), with supramaximal current pulses of $0.05 \mathrm{~ms}$ duration, at $0.1,1$ or to $10 \mathrm{~Hz}$ frequencies, delivered by the isolation unit of a stimulator (S-44 Grass Instruments, West Warwick, USA). The quantal content $(m)$ of the EPP was assessed directly as the ratio of the average EPP amplitude and the average mEPP amplitude (at least 25 MEPPs and 75 EPPs were averaged). EPPs with amplitude exceeding $3 \mathrm{mV}$ were corrected for nonlinear summation of EPPs (McLachlan and Martin 1981). The equilibrium potential for ACh used in the calculations was $0 \mathrm{mV}$. When the quantal content of EPPs was low, the following equation, based on Poisson statistics, was used:

$m=\ln (\mathrm{N} / \mathrm{No})$, where $m$ is the average number of transmitter quanta released per impulse, $N$ is the total number of stimulations, and $N o$ is the corresponding number of failures of release (i.e., the number of stimuli not followed by an EPP). Signals were collected, amplified and digitized with the aid of a computer equipped with a Digidata-1322A A/D interface board (Axon Instruments, Molecular Devices, Sunnyvale, CA, USA). Data acquisition and analysis were performed with the WinWCP V3.9.6 software program, kindly provided by Dr. John Dempster (University of Strathclyde, Scotland). All experiments were carried out, unless indicated, at constant room temperature $\left(22^{\circ} \mathrm{C}\right)$.

\section{Nerve terminal calcium signal imaging}

To load the cell permeable fluorescent indicator of intracellular $\mathrm{Ca}^{2+}$ into nerve terminals, the cut end of the frog pectoralis proprius nerve trunk stump (about $2 \mathrm{~mm}$ length) was incubated for 90$120 \mathrm{~min}$ in the dark, with the standard physiological solution containing fluo3/AM $(5.4 \mu \mathrm{M})$ with $0.02 \%$ pluronic acid (w/v), in a different compartment from the one containing the cutaneous pectoris muscle of a special recording chamber designed to fit on an upright microscope; To visualize muscle $\mathrm{nAChR}$ the preparation was incubated for 20 min with $\alpha$-Bungarotoxin Alexa Fluor ${ }^{\mathrm{TM}} 594$ conjugate (Invitrogen, Molecular Probes). Then, the nerve and muscle compartments were washed at a flow rate of $10 \mathrm{~mL} \mathrm{~min}{ }^{-1}$ for $15-30$ min with the standard physiological solution. The dual compartment chamber with the nerve-muscle preparation was placed in the microscope stage of an up-right multiphoton scanning confocal microscope (LSM 510 META; Carl Zeiss, Germany), and controlled through the manufacturer supplied software and workstation. Nerve stimulation was performed, with a suction microelectrode controlled by a micromanipulator that could fit into the working distance $(1.7 \mathrm{~mm})$ of the water-immersion lens (Plan-Apochromat 20 X/1.0 N.A.). Fluo3/AM was excited with the 488-nm wavelength line of an Argon ion laser, and Alexa-594 $\alpha$-bungarotoxin with the 561-nm wavelength line of a DPSS laser. The pinhole aperture was set to 1 Airy Unit. Images were digitized for time-laps series at 8bit into a 256x256 pixel array (up to 10 frames per second) or, at a 12-bit resolution into a $512 \times 512$ pixel array (up to 5 frames per second). Fluorescence images were collected and analyzed frame by frame and processed identically using Zen ${ }^{\circledR}$ software (Carl Zeiss, Germany). The mean nerve terminal fluorescence was outlined before $\left(\mathrm{F}_{0}\right)$ and during gambierol treatment $(\Delta \mathrm{F})$. The relative fluorescence was calculated as $\Delta \mathrm{F} / \mathrm{F}_{0}$ percentage. 


\section{Statistical analyses}

The results are expressed as the mean \pm S.E.M. Statistical differences were calculated using either paired or unpaired Student's $t$-test. $P$ values $<0.05$ were considered statistically significant.

\section{Results}

Effects of gambierol on spontaneous and stimulus-evoked quantal transmitter release

To determine if gambierol had an action on spontaneous quantal transmitter release, the mEPP frequency was measured, by intracellular recordings, at mouse and frog resting neuromuscular preparations equilibrated in standard physiological solution. The mEPP frequency was not significantly modified by concentrations of $0.2-10 \mathrm{nM}$ gambierol, applied for $30 \mathrm{~min}$, to mouse hemidiaphragm $\left(1.61 \pm 0.07 \mathrm{~s}^{-1}, \mathrm{n}=40\right.$ junctions from 5 different muscles treated with $10 \mathrm{nM}$ gambierol , vs $1.57 \pm 0.08 \mathrm{~s}^{-1}, \mathrm{n}=30$ junctions from 3 control muscles, $\left.P=0.724\right)$. Under control conditions the mean resting potential of muscle fibers was $-69.2 \pm 2.8 \mathrm{mV}$. After 2,10 and $20 \mathrm{nM}$ gambierol treatment for $30 \mathrm{~min}$, it was $-67.9 \pm 2.7,-68.2 \pm 1.9$ and $-69.6 \pm 2.2 \mathrm{mV}$, respectively ( $\mathrm{n}=28$ to 36 fibers sampled from 6 different hemidiaphragms for each condition). These results indicate that gambierol, in the range of concentrations studied had no significant action on the resting membrane potential of muscle fibers $(P>0.05)$. Similarly, no change was detected on the $\mathrm{mEPP}$ frequency in frog cutaneous pectoris muscles treated with $0.5-20 \mathrm{nM}$ gambierol $(0.50 \pm$ $0.07 \mathrm{~s}^{-1}, \mathrm{n}=21$ junctions from 5 different muscles treated with $20 \mathrm{nM}$ gambierol, $v \mathrm{~s} 0.48 \pm 0.03$ $\mathrm{s}^{-1}, \mathrm{n}=19$ junctions from 3 control muscles, $P=0.851$ ). As illustrated in Fig. $2 \mathrm{~A}$, gambierol (100 $\mathrm{nM}$ ) did not change significantly the spontaneous mEPP frequency in resting unstimulated junctions bathed in standard physiological solution. However, multiquantal spontaneous events that had 5 to 10 times the amplitude of mEPPs were frequently recorded under those conditions (Fig. 2B). Such large synaptic events were completely suppressed by blocking nerve conduction with $1 \mu \mathrm{M}$ tetrodotoxin added to the standard solution. It is thus likely that such events are due to gambierol-induced, tetrodotoxin-sensitive spontaneous nerve action potentials which, in turn, triggered synchronous multiquantal release.

\section{Fig. 2 near here}

To verify if gambierol had an action on evoked transmitter release, hemidiaphragm preparations were equilibrated for $30 \mathrm{~min}$ in a low- $\mathrm{Ca}^{2+}(0.4 \mathrm{mM})$ and high- $\mathrm{Mg}^{2+}(8.0 \mathrm{mM})$ physiological medium, to evaluate the mean quantal content $(m)$ of EPPs. Under control conditions, $m$ values ranged between 0.3 and 1.5 (with a coefficient of variation $=0.53$ ), and mean $m$ value of $0.70 \pm$ 0.07 ( $\mathrm{n}=26$ junctions, 5 muscles), indicating that a proportion of nerve stimuli failed to release the transmitter and to evoke an EPP. Interestingly, after 20 min equilibration with nanomolar gambierol concentrations, most of the junctions examined had no failure of release upon nerve stimulation, and mean $m$ values were markedly increased several fold, as shown in the 
concentration-response curve of Fig. 3. On equimolar basis gambierol was more potent than 3,4DAP, in enhancing stimulus evoked quantal transmitter release.

\section{Fig. 3 near here}

To make clear if the ability of gambierol to enhance evoked quantal release was related to an action on the presynaptic action potential, local circuit currents were recorded with an extracellular microelectrode, using techniques previously developed (Katz and Miledi, 1965a,b; Brigant and Mallart, 1982. The fire-polished microelectrode was gently placed, under visual control, on the nerve terminal of a single neuromuscular junction of the LAL muscle. Representative focal current recordings performed in a Krebs-Ringer solution containing dtubocurarine $(3.5 \mu \mathrm{M})$ to block neuromuscular transmission are shown in Fig. 3. The two positive signals correspond to the typical presynaptic currents seen in recordings done at terminal parts of the nerve terminal branches of mammalian junctions (Brigant and Mallart, 1982). The first peak relates to the capacity current (IC) leaving the terminal, due to the $\mathrm{Na}^{+}$influx into the nodes of Ranvier of the parent axon. The second peak corresponds to a fast $\mathrm{K}^{+}$current (IK) generated in the nerve terminals (see Fig. 4). Gambierol addition to the medium caused, within 10-15 min, a reduction of the IK signal of presynaptic currents (i.e. of $57.2 \pm 1.6 \%$ at $2 \mathrm{nM}$ and $80.3 \pm 2.2 \%$ at $10 \mathrm{nM}, \mathrm{n}=6$ ), without affecting the IC component (Fig. 4). These results strongly indicate that gambierol prolongs the duration of the presynaptic action potential due to the blockade of the fast IK current in motor nerve terminals. Also, when measuring the synaptic delay, from the peak of the presynaptic IC component to the beginning of the postsynaptic current (see Fig. 4A), in the presence of $2 \mathrm{nM}$ gambierol the synaptic delay increased significantly by $23.2 \pm 0.9 \%$ ( $\mathrm{n}=5$ junctions from 2 LAL muscles with respect to controls, $P<0.05)$. The synaptic delay in frog cutaneous pectoris junctions equilibrated with $3 \mu \mathrm{M}$ d-tubocurarine, measured as the interval between the negative peak of the presynaptic spike and the start of the local inward current through the postsynaptic membrane (Katz and Miledi, 1965b), was also significantly increased by $20 \mathrm{nM}$ gambierol with respect to control, as shown in the graphs of Fig. 4B.

\section{Fig. 4 near here}

\section{Gambierol increases EPP amplitudes and reverses the block produced by d-tubocurarine}

Since gambierol increased the quantal content of EPPs, it was relevant to study whether it was able to antagonize the action of d-tubocurarine, a competitive inhibitor of ACh binding to muscle nAChRs (Colquhoun et al., 1979). For this, frog cutaneous pectoris neuromuscular preparations, in which excitation-contraction was uncoupled, were equilibrated for $45 \mathrm{~min}$ in standard physiological solution containing $5 \mu \mathrm{M}$ d-tubocurarine. Under these conditions, only subthreshold EPPs (3-5 mV amplitude) were recorded at a normal resting membrane potential ($80 \mathrm{mV})$. Gambierol (3 nM) significantly increased EPP amplitudes to 8-10 $\mathrm{mV}(\mathrm{n}=4$ junctions,

from 4 different muscles, $P<0.05$ ), but EPPs remained subthreshold for action potential generation. Complete reversal of d-tubocurarine action was obtained with $5 \mathrm{nM}$ gambierol concentrations, which allowed EPPs to reach the threshold for action potential generation ( -56 to 
$-58 \mathrm{mV}$ ) in the muscle fiber, as shown in a representative experiment (Fig. 5A). Under those conditions the nerve-evoked muscle action potentials had overshoots comprised between 20-27 $\mathrm{mV}$ amplitude $(\mathrm{n}=4)$.

Gambierol also increased the amplitude of EPPs in frog neuromuscular preparations pretreated with $\mu$-conotoxin GIIIB (1.0-1.6 $\mu \mathrm{M})$. Under this condition, EPPs were recorded in the absence of muscle action potentials, and $15 \mathrm{nM}$ gambierol increased the peak amplitude of nerve-elicited EPPs up to $473 \pm 20.2 \%$ of control values ( $\mathrm{n}=4$ junctions, 4 different muscles, $\mathrm{P}<0.05$ ). As shown in Fig. 5B, in the presence of gambierol, the peak EPP amplitude not only was rather flat, but in some cases also reached the equilibrium potential of ACh (about $0 \mathrm{mV}$ ), at which there is not net ion fluxes through the nAChR activated channel. Also, it was striking the marked increase in the time course of the EPP. When computing the integral of the EPP area, gambierol was found to increase the EPP area by $863.2 \pm 44.6 \%$ with respect to controls values ( $n=4$ junctions, 4 different muscles, $\mathrm{P}<0.05$ ).

\section{Fig. 5 near here}

\section{Gambierol enhances delayed asynchronous quantal release}

When reducing transmitter release, following nerve stimulation that triggers EPPs there is a period of elevated spontaneous quantal release that is known as delayed quantal release. In order to determine whether gambierol affected delayed release, frog and mouse neuromuscular preparations were pre-treated with $\mu$-conotoxin GIIIB (1.0-1.6 $\mu \mathrm{M})$ and equilibrated in standard physiological solutions in order to evaluate the delayed quantal release i.e., the number of mEPPs appearing after the EPP evoked by nerve stimulation. A typical example of an EPP, evoked at 1 $\mathrm{Hz}$ nerve stimulation, and recorded in the presence of gambierol $(2 \mathrm{nM})$ that was followed by several mEPPs is shown in Fig. 6A. Since the number of delayed releases per stimulus was markedly dependent on the concentration of gambierol, the time of nerve stimulation, and the previous history of nerve stimulation. We standardized the number of stimuli given to the motor nerve and used different preparations for each concentration of gambierol tested. The graphs in Fig. 6B, summarizes the results obtained under control conditions, and after 10, 20 and $100 \mathrm{nM}$ gambierol treatment. It is quite striking the concentration-dependent action of gambierol on delayed release, and the fact that high number of events could still be recorded several hundred milliseconds after the phasic EPP. This may be due to the possibility that $\mathrm{Ca}^{2+}$ entry into nerve terminals was enhanced by gambierol and that delayed release could be triggered by residual $\mathrm{Ca}^{2+}$ remaining in the terminals.

\section{Fig. 6 near here}

\section{Gambierol reversed the presynaptic block produced by BoNT/A ex vivo}

BoNT/A is a bacterial $\mathrm{Zn}^{2+}$ metalloprotease acting in the nerve terminal cytosol of cholinergic synapses where it selectively cleaves the synaptosomal-associated protein of $25 \mathrm{kDa}$ (SNAP-25) (Blasi et al., 1993) a core protein of the neuroexocytosis apparatus (Shiavo et al., 2000) causing at the neuromuscular junction a long-lasting inhibition of neurotransmitter release (Meunier et al., 
2002). In view that 3,4-DAP has been shown to be effective in increasing evoked quantal release from BoNT/A-poisoned rat EDL muscles (Molgó et al., 1980), it was of interest to determine if gambierol had also an action on evoked quantal release from junctions treated with the neurotoxin. After the local intramuscular injection of BoNT/A into the hind limb of mice, the degree of muscle paralysis monitored in vivo using the DAS assay showed that all 6 mice injected had a DAS score of 4 and were paralyzed 24 h, 48 and $72 \mathrm{~h}$ after the injection. Mice injected with the vehicle to dilute the toxin $(n=4)$ had a DAS score of 0 and were normal. At $72 \mathrm{~h}$ after BoNT/A-injection, the deep peroneal nerve-EDL muscle preparations were removed from BoNT/A-treated animals and analyzed ex vivo for neurotransmitter release. Spontaneous mEPP frequency was markedly reduced from $1.68 \pm 0.20 \mathrm{~s}^{-1}(\mathrm{n}=12$ junctions, from muscles isolated from 4 vehicle-injected mice) to $0.020 \pm 0.003 \mathrm{~s}^{-1}(\mathrm{n}=12$ junctions, from muscles isolated from 6 BoNT/A-treated mice). In BoNT/A-treated junctions, the few evoked synaptic responses recorded were mono-quantal (Fig. 7A). The addition of $15 \mathrm{nM}$ gambierol to the medium markedly reduced the number of failures of release, and increased the amplitude of EPPs, most of which were multiquantal, as shown in Fig. 7A. Such EPPs could restore muscle twitches evoked by nerve stimulation in most muscle fibers. Comparison of the mean quantal content of EPPs, calculated using the failure method for controls, and estimated from EPPs/mEPPs ratio in the presence of gambierol, showed that the polyether was able to increase significantly $(P<0.05)$, by a factor close to 100-fold, the mean quantal content of EPPs in BoNT/A treated neuromuscular junctions (Fig. 7B). Concentrations of gambierol higher than $20 \mathrm{nM}$ completely antagonized the muscle paralysis caused by BoNT/A, and evoked muscle twitches upon every nerve stimulation (not shown). Thus, gambierol at nanomolar concentrations is able to reverse the block of stimulusevoked quantal release in BoNT/A-poisoned junctions.

\section{Fig. 7 near here}

\section{Gambierol incrases $\mathrm{Ca}^{2+}$ signals in motor nerve terminals}

Frog nerve-muscle preparations, in which excitation was uncoupled from contraction, were loaded with fluo-3-AM, treated with $\alpha$-Bungarotoxin ( $\alpha$-BgTx) Alexa Fluor ${ }^{\mathrm{TM}} 594$ conjugate to both localize nAChRs and block eventual $\mathrm{Ca}^{2+}$ influx through the activated nAChR channel, and imaged using fast confocal microscopy. Nerve terminals were stimulated with trains of $1 \mathrm{~Hz}$ (20$25 \mathrm{~s}$ duration), $10 \mathrm{~Hz}(12-15 \mathrm{~s})$ and $1 \mathrm{~Hz}(17-25 \mathrm{~s})$ followed by an unstimulated period, as shown in a typical experiment (Fig. 8) . Under control conditions (Fig. 8B; supplementary video Movie S1), nerve stimulation with trains of $1 \mathrm{~Hz}$ evoked tiny phasic $\mathrm{Ca}^{2+}$ signals, that were distinguishable from the basal level, and which fluctuated in amplitude between events in the train. These event represented transient increases in fluorescence of 9-14\% $(\Delta \mathrm{F} / \mathrm{F} ; \mathrm{n}=6)$. Nerve stimulation with trains of $10 \mathrm{~Hz}$ caused saw-toothed signals that fused reaching about 100 -fold the basal fluorescence level. At the end of the $10 \mathrm{~Hz}$ stimulation period, the $\mathrm{Ca}^{2+}$ signal represented about 10-12-times the level of fluorescence $(\Delta \mathrm{F} / \mathrm{F})$ observed at $1 \mathrm{~Hz}$ nerve stimulation. After the $10 \mathrm{~Hz}$ stimulation, continuous $1 \mathrm{~Hz}$ stimulation induced again similar tiny 
transient phasic $\mathrm{Ca}^{2+-}$ signals. As shown in Fig. 8A, the basal fluorescence after the $10 \mathrm{~Hz}$ nerve stimulation equilibrated to a new higher level that was about 2.5-3 times the level recorded during the $1^{\text {st }}$ train at $1 \mathrm{~Hz}$, and returned in the absence of nerve stimulation, to the basal level with a time constant $(\tau)=6.2-7.3 \mathrm{~s}$.

After equilibration with $50 \mathrm{nM}$ gambierol, and using a similar pattern of nerve stimulation (see Fig. 8C; supplementary video Movie S2), the relative intracellular $\mathrm{Ca}^{2+}$-fluorescence signals of nerve terminals were markedly increased both at 1 and $10 \mathrm{~Hz}$, compared to controls values (Fig. 8B). Calcium transients at $1 \mathrm{~Hz}$ nerve stimulation were increased by about $200 \%$, and at $10 \mathrm{~Hz}$ by about $361 \%$. In addition, with continuous stimulation the relative basal fluorescence was also increased. The phase of decrease of the relative $\mathrm{Ca}^{2+}$ fluorescence, after stopping nerve stimulation was also much prolonged in the presence of gambierol, with fast and slow kinetics. These results strongly indicate that phasic $\mathrm{Ca}^{2+}$ signals markedly increase with gambierol treatment, and suggest that the increase in presynaptic action potential duration leads to an important increase in the $\mathrm{Ca}^{2+}$ influx into the motor nerve terminals. It is worth noting that the calcium transients observed in the presence of gambierol upon nerve stimulation $(1 \mathrm{and} 10 \mathrm{~Hz})$ were completely suppressed when blocking nerve conduction with $1 \mu \mathrm{M}$ tetrodotoxin.

Fig. 8 near here

\section{Discussion}

The present experimental results demonstrate for the first time that the synthetic polyether toxin gambierol, at nanomolar concentrations, is able to markedly enhance stimulus-evoked quantal transmitter release at mouse and frog neuromuscular junctions, without affecting the resting membrane potential of muscle fibers. Thus, gambierol reversed the postsynaptic neuromuscular blockade produced by d-tubocuranine, and the presynaptic block caused by low calcium-high magnesium medium, as evidenced by the increase in the amplitude of EPPs and the quantal content of EPPs, respectively. Gambierol, on equimolar basis, was found to be more potent than 4-aminopyridine or 3,4-DAP (Molgó et al., 1975; Molgó et al., 1980) well-known Kv-channel blockers that markedly potentiate evoked transmitter release at motor nerve (Heuser et al., 1977; Molgó et al., 1982; Katz and Miledi, 1979).

Spontaneous quantal transmitter release, measured by recording mEPP frequency in resting junctions, was not significantly modified by gambierol; this is in marked contrast to the action of other polyether toxins like ciguatoxins, also produced by dinoflagellates of the genus Gambierdiscus that produce gambierol. The increase in mEPP frequency with ciguatoxins ends with the depletion of synaptic vesicles from nerve terminals, and can be completely prevented or blocked by tetrodotoxin. Such actions are related to the activation of voltage-gated Na channels and to the block of synaptic vesicle recycling (Molgó et al., 1992).

Gambierol and analogs are known to inhibit native or expressed mammalian Kv channel subtypes 
in neuronal cells (Ghiaroni et al., 2005; Cuypers et al., 2008; Pérez et al., 2012; Konoki et al., 2015), and Xenopus skeletal myocytes (Schlumberger et al., 2010). Present results indicate that also motor nerve terminals of vertebrate neuromuscular junction are sensitive to nanomolar concentrations of gambierol, as shown by the reduction of the fast IK current generated in the nerve endings, using external focal current recordings in mammalian junctions. Blockade of the fast IK current in motor nerve terminals by gambierol lengthened the presynaptic action potential duration, increased the synaptic delay and increased evoked quantal transmitter release. Thus, these results support the view that the fast $\mathrm{K}^{+}$current in nerve terminals is extremely important for regulating the duration of the presynaptic action potential, playing an important role in the control of the amount of $\mathrm{Ca}^{2+}$ entry into the terminal and therefore in the number of quanta released upon nerve stimulation (Van der Kloot and Molgó, 1994).

Interestingly, gambierol was also found to reverse the block of stimulus-evoked quantal transmitter release produced by BoNT/A in mouse neuromuscular junction poisoned in vivo and examined ex vivo. BoNT/A is known to cleave a small segment of nine amino acid residues of the C-terminal region of SNAP25 (Blasi et al., 1993). However, several lines of evidence indicate that cleaved SNAP-25 can still establish a stable complex with syntaxin and VAMP/synaptobrevin, the so-called soluble N-ethylmaleimide-sensitive factor attachment protein receptor (SNARE) complex which conveys synaptic vesicles into close contact with the nerve terminal membrane (Sutton et al., 1998). This apposition is mandatory for subsequent steps of membrane fusion and transmitter release (reviewed by Schiavo et al., 2000). The fact that few transmitter quanta were released in the BoNT/A-poisoned junctions and that gambierol treatment significantly increased more than a hundred-fold the mean quantal content of EPPs further indicates that the capability of truncated SNAP-25 to form stable single or multi complexes is not completely impaired (see Pantano and Montecucco, 2014).

$\mathrm{Ca}^{2+}$ is essential for neurotransmitter release as shown by the pioneering studies of Katz and Miledi (1965c). In the present study gambierol was found to markedly increase $\mathrm{Ca}^{2+}$ transients upon nerve stimulation at 1 and $10 \mathrm{~Hz}$ in terminals loaded with fluo-3/AM; The robust increase in phasic calcium signals in the presence of gambierol can be related to an enhanced $\mathrm{Ca}^{2+}$ entry during the presynaptic action potential and to the observed increase in evoked quantal transmitter release. Delayed transmitter release which has been attributed to residual $\mathrm{Ca}^{2+}$ was also increased during gambierol action. Interestingly, with repeated stimulation at $1 \mathrm{~Hz}$, in the presence of gambierol, the basal fluorescent level increase with every stimulus. When stopping nerve stimulation at $1 \mathrm{~Hz}$ the basal fluorescence level remained relatively high, suggesting that residual $\mathrm{Ca}^{2+}$ is involved in the asynchronous release following the phasic one. In addition, the results suggest that residual $\mathrm{Ca}^{2+}$ is proportional to the amount of $\mathrm{Ca}^{2+}$ entering to trigger the phasic release quantal release. Gambierol in high concentrations (0.1-30 $\mu \mathrm{M})$ was reported to evoke intracellular highly synchronous $\mathrm{Ca}^{2+}$ oscillations at single cerebellar granule cells in culture (Alonso et al., 2010). Also, inhibition of $\mathrm{Kv}$ channels by gambierol augmented spontaneous $\mathrm{Ca}^{2+}$ 
oscillations in cerebro cortical neurons (Cao et al., 2014). Such actions were mimicked by other $\mathrm{Kv}$ inhibitors including 4-aminopyridine and tetraethylammonium.

\section{Conclusion}

Altogether, the results here presented show for the first time that gambierol enhances quantal transmitter release in normal and in BoNT/A-treated junctions in response to nerve stimulation. On equimolar basis, gambierol is more potent than 3,4-diaminopyridine. Although spontaneous quantal release is unaffected by gambierol in resting junctions, nerve stimulation markedly enhanced delayed quantal release in a concentration-dependent manner. Changes in quantal release detected seem to be due to the blockade of the fast $\mathrm{K}^{+}$current in nerve terminals and the concomitant enhanced $\mathrm{Ca}^{2+}$ influx that triggers phasic and delayed release. Further studies will be needed to fully understand the mechanism(s) involved in the action of gambierol at motor nerve terminals. In particular, the handling of $\mathrm{Ca}^{2+}$ by intracellular $\mathrm{Ca}^{2+}$ stores. Our results strongly suggest that gambierol, or synthetic analogues, can have potential medical application in neuromuscular conditions in which it is necessary to antagonize pre- or post-synaptic neuromuscular blockade, or both.

\section{Competing Interest}

The authors declare no conflict of interest.

\section{Acknowledgements}

This study was supported in part by the project ALERTOX-NET (EAPA_317/2016) funded by the Interreg Atlantic program, and in part by the CNRS. We thank Professor Michel Robert Popoff (Pasteur Institute, Paris) for providing the BoNT/A used in the present study, Mrs Patricia Villeneuve for excellent technical assistance, and Professor Roland Bournaud for helpful discussions in the course of this work.

\section{References}

Alonso E, Vale C, Sasaki M, Fuwa H, Konno Y, Perez S, Vieytes MR, Botana LM. (2010) Calcium oscillations induced by gambierol in cerebellar granule cells. J Cell Biochem 110(2):497-508. doi: 10.1002/jcb.22566.

Alonso E, Fuwa H, Vale C, Suga Y, Goto T, Konno Y, Sasaki M, LaFerla FM, Vieytes MR, Giménez-Llort L, Botana LM. (2012) Design and synthesis of skeletal analogues of gambierol: attenuation of amyloid- $\beta$ and tau pathology with voltage-gated potassium channel and N-methylD-aspartate receptor implications. J Am Chem Soc 134(17):7467-7479. doi: 10.1021/ja300565t. 
Angaut-Petit D, Molgo J, Connold AL, Faille L. (1987) The levator auris longus muscle of the mouse: a convenient preparation for studies of short- and long-term presynaptic effects of drugs or toxins. Neurosci Lett 82(1):83-88. doi.org/10.1016/0304-3940(87)90175-3.

Aoki KR. (2001) A comparison of the safety margins of botulinum neurotoxin serotypes A, B and F in mice. Toxicon 39(12):1815-1820. doi.org/10.1016/S0041-0101(01)00101-5.

Blasi J, Chapman ER, Link E, Binz T, Yamasaki S, De Camilli P, Südhof TC, Niemann H, Jahn R. (1993) Botulinum neurotoxin A selectively cleaves the synaptic protein SNAP-25. Nature 365(6442):160-163.

Brigant JL, Mallart A. (1982) Presynaptic currents in mouse motor endings. J Physiol 333:619636.

Cao Z, Cui Y, Busse E, Mehrotra S, Rainier JD, Murray TF. (2014) Gambierol inhibition of voltage-gated potassium channels augments spontaneous $\mathrm{Ca}^{2+}$ oscillations in cerebro cortical neurons. J Pharmacol Exp Ther 350(3):615-623. doi: 10.1124/jpet.114.215319.

Colquhoun D, Dreyer F, Sheridan RE. (1979) The actions of tubocurarine at the frog neuromuscular junction. J Physiol 293:247-284. 284. doi.org/10.1113/jphysiol.1979.sp012888.

Cuypers E, Abdel-Mottaleb Y, Kopljar I, Rainier JD, Raes AL, Snyders DJ, Tytgat J. (2008) Gambierol, a toxin produced by the dinoflagellate Gambierdiscus toxicus, is a potent blocker of voltage-gated potassium channels. Toxicon 51(6):974-83. doi: 10.1016/j.toxicon.2008.01.004.

Cruz LJ, Gray WR, Olivera BM, Zeikus RD, Kerr L, Yoshikami D, Moczydlowski E. (1985) Conus geographus toxins that discriminate between neuronal and muscle sodium channels. J Biol Chem 260(16):9280-9288.

Del Castillo J, Escalona de Motta G. (1978) A new method for excitationcontraction uncoupling in frog skeletal muscle. J Cell Biol 78(3):782-784. doi: 10.1083/jcb.78.3.782.

Darius HT, Roué M, Sibat M, Viallon J, Gatti CMII, Vandersea MW, Tester PA, Litaker RW, Amzil Z, Hess P, Chinain M. (2018) Toxicological Investigations on the Sea Urchin Tripneustes gratilla (Toxopneustidae, Echinoid) from Anaho Bay (Nuku Hiva, French Polynesia): Evidence for the Presence of Pacific Ciguatoxins. Mar Drugs 16(4). pii: E122. doi: 10.3390/md16040122.

Fuwa H, Kainuma N, Tachibana K, Sasaki M. (2002) Total synthesis of (-)-gambierol. J Am Chem Soc 124(50):14983-14992. doi: 10.1021/ja028167a.

Furuta H, Hasegawa Y, Mori Y. (2009) Total synthesis of gambierol. Org Lett 11(19):4382-4385. doi: $10.1021 / 019017408$.

Ghiaroni V, Sasaki M, Fuwa H, Rossini GP, Scalera G, Yasumoto T, Pietra P, Bigiani A. (2005) Inhibition of voltage-gated potassium currents by gambierol in mouse taste cells. Toxicol Sci 85:657-665. doi: 10.1093/toxsci/kfi097. 
Heuser JE, Reese TS, Dennis MJ, Jan Y, Jan L, Evans L. (1979) Synaptic vesicle exocytosis captured by quick freezing and correlated with quantal transmitter release. J Cell Biol 81(2):275300.

Johnson, H.W., Majumder, U., and Rainier, J.D. (2005) The total synthesis of gambierol. J Am Chem Soc 127:848-849.

Katz B, Miledi R. (1965a) Propagation of electric activity in motor nerve terminals. Proc Roy Soc B 161:453-482.

Katz B, Miledi R. (1965b) The measurement of synaptic delay, and the time course of acetylcholine release at the neuromuscular junction. Proc Roy Soc B 161:483-495.

Katz, B. \& Miledi, R. (1965c) The effect of calcium on acetylcholine release from motor nerve terminals. Proc Roy Soc B 161:496-503.

Katz B, Miledi R (1979) Estimates of quantal content during "chemical potentiation" of transmitter release. Proc R Soc Lond B Biol Sci 205:369-378.

Konoki K, Suga Y, Fuwa H, Yotsu-Yamashita M, Sasaki M. (2015) Evaluation of gambierol and its analogs for their inhibition of human Kv1.2 and cytotoxicity. Bioorg Med Chem Lett 25(3):514-518. doi: 10.1016/j.bmcl.2014.12.022.

Kopljar I, Labro AJ, Cuypers E, Johnson HW, Rainier JD, Tytgat J, Snyders DJ. (2009) A polyether biotoxin binding site on the lipid-exposed face of the pore domain of $\mathrm{Kv}$ channels revealed by the marine toxin gambierol. Proc Natl Acad Sci U S A 106(24):9896-9901. doi: 10.1073/pnas.0812471106.

Larsson ME, Laczka OF, Harwood DT, Lewis RJ, Himaya SWA, Murray SA, Doblin MA. (2018) Toxicology of Gambierdiscus spp. (Dinophyceae) from tropical and temperate Australian waters. Mar Drugs 16(1). pii: E7. doi: 10.3390/md16010007.

McLachlan EM, Martin AR. (1981) Non-linear summation of end-plate potentials in the frog and mouse. J Physiol 311:307-324.

Meunier FA, Schiavo G, Molgó J. (2002) Botulinum neurotoxins: from paralysis to recovery of functional neuromuscular transmission. J Physiol Paris 96(1-2):105-113.

Molgó J, Lemeignan M, Lechat P. (1975) Changes in transmitter release at frog neuromuscular junction induced by 4-aminopyridine. C R Acad Sci Hebd Seances Acad Sci D 281(21):16371639.

Molgó J, Lundh H, Thesleff S. (1980) Potency of 3,4-diaminopyridine and 4-aminopyridine on mammalian neuromuscular transmission and the effect of pH changes. Eur J Pharmacol 61:25-34. 
Molgó J. (1982) Effects of aminopyridines on neuromuscular transmission. In: Aminopyridines and similarly acting drugs - Effects on Nerves, Muscles and synapses. Advances in the Biosciences (Lechat P, Thesleff S, Bowman WC, eds), Pergamon Press, London, pp. 95-116.

Molgó J, Benoit E, Comella JX, Legrand AM. (1992) Ciguatoxin: A tool for research on sodiumdependent mechanisms. In: Methods in Neuroscience, Vol. 8, Neurotoxins (Conn PM, Ed), pp 149-164. Academic Press Inc. Boston.

Mori Y. (2019) Development of new synthetic methods using oxiranyl anions and application in the syntheses of polycyclic ether marine natural products. Chem Pharm Bull (Tokyo) 67(1):1-17. doi: 10.1248/cpb.c18-00699.

Nicolaou KC, Frederick MO, Aversa RJ. (2008) The continuing saga of the marine polyether biotoxins. Angew Chem Int Ed Engl 47(38):7182-7225. doi: 10.1002/anie.200801696.

Pantano S, Montecucco C. (2014) The blockade of the neurotransmitter release apparatus by botulinum neurotoxins. Cell Mol Life Sci 71(5):793-811.

Pérez S, Vale C, Alonso E, Fuwa H, Sasaki M, Konno Y, Goto T, Suga Y, Vieytes MR, Botana LM. (2012) Effect of gambierol and its tetracyclic and heptacyclic analogues in cultured cerebellar neurons: a structure-activity relationships study. Chem Res Toxicol 25(9):1929-1937. doi: 10.1021/tx300242m. Aug 29.

Rubiolo JA, Vale C, Martín V, Fuwa H, Sasaki M, Botana LM. (2015) Potassium currents inhibition by gambierol analogs prevents human $\mathrm{T}$ lymphocyte activation. Arch Toxicol 89(7):1119-34. doi: 10.1007/s00204-014-1299-2.

Satake M, Murata M, Yasumoto T. (1993) Gambierol: a new toxic polyether compound isolated from the marine dinoflagellate Gambierdiscus toxicus. J Am Chem Soc 115:361-362.

Schiavo G, Matteoli M, Montecucco C. (2000) Neurotoxins affecting neuroexocytosis. Physiol Rev 80(2):717-766.

Schlumberger S, Ouanounou G, Girard E, Sasaki M, Fuwa H, Louzao MC, Botana LM, Benoit E, Molgó J. (2010) The marine polyether gambierol enhances muscle contraction and blocks a transient $\mathrm{K}(+)$ current in skeletal muscle cells. Toxicon 56(5):785-791. doi: 10.1016/j.toxicon.2010.06.001.

Sutton RB, Fasshauer D, Jahn R, Brunger AT.(1998) Crystal structure of a SNARE complex involved in synaptic exocytosis at 2.4 A resolution. Nature 395(6700):347-353.

Van der Kloot W, Molgó J. (1994) Quantal acetylcholine release at the vertebrate neuromuscular junction. Physiol Rev 74(4):899-991.

Yasumoto T. (2001) The chemistry and biological function of natural marine toxins. Chem Rec $1(3): 228-242$. 


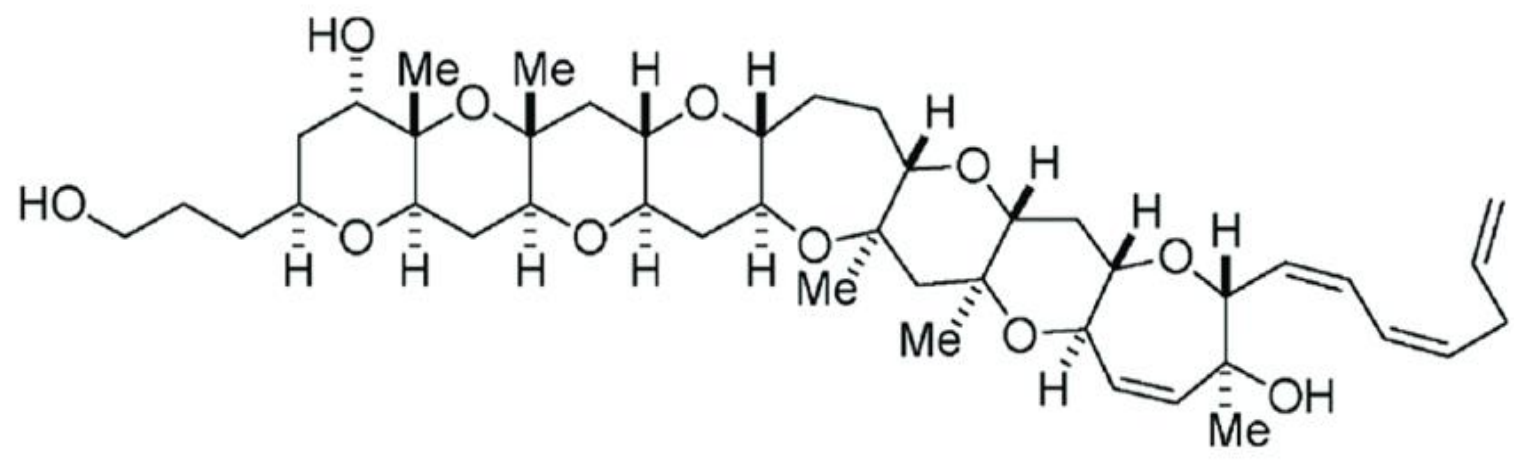

Figure 1. Chemical structure of gambierol. 

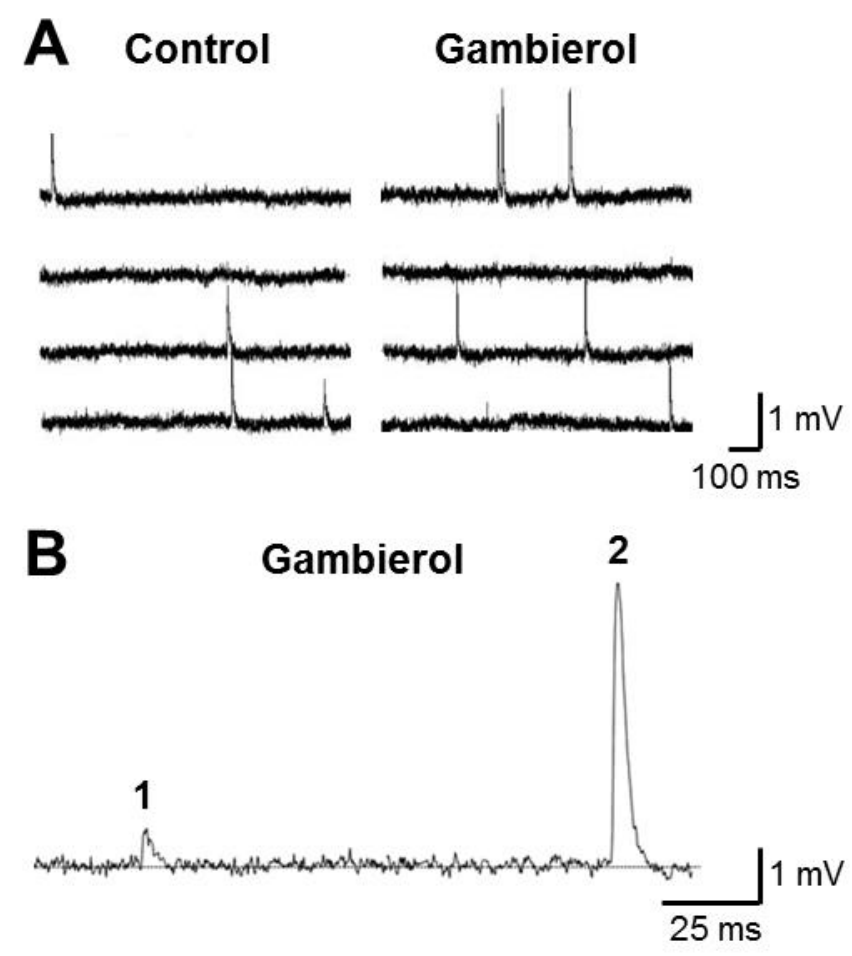

Figure 2. (A) Spontaneous mEPPs recorded in a resting unstimulated junction of the mouse hemidiaphram, before (Control) and after $20 \mathrm{~min}$ exposure to $100 \mathrm{nM}$ gambierol. Note the lack of gambierol effect on mEPP frequency. (B) Typical monoquantal mEPP (1) followed by a spontaneous multiquantal event (2), recorded in an unstimulated frog cutaneous pectoris muscle. The mean resting membrane potential during measurements was $-70.8 \mathrm{mV}$ in $\mathrm{A}$ and $-80 \mathrm{mV}$ in $\mathrm{B}$. 


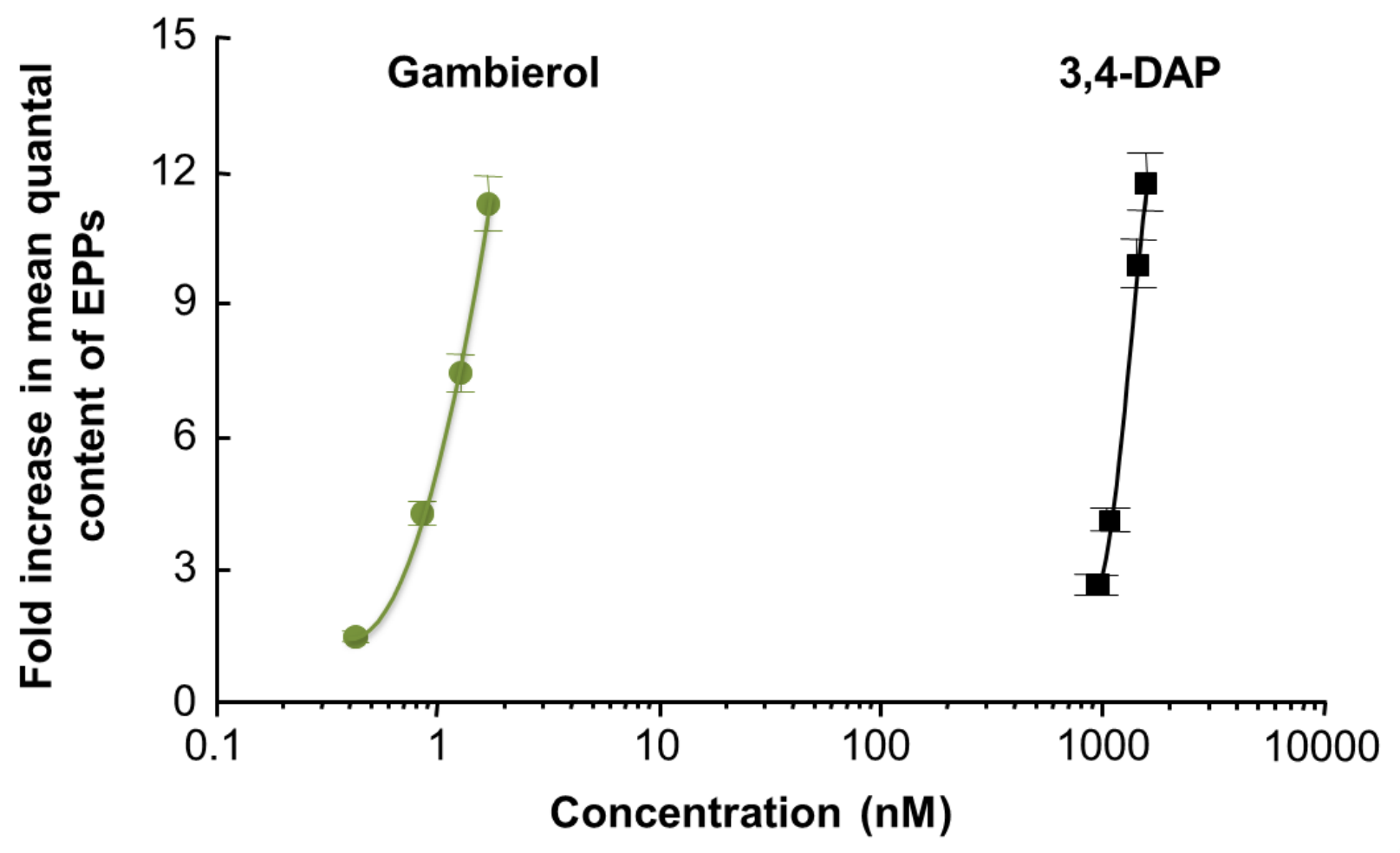

Figure 3. Gambierol and 3,4-diaminopyridine (3,4-DAP) increased the mean quantal content of EPPs in mouse neuromuscular junctions equilibrated in a low $\mathrm{Ca}^{2+}(0.4 \mathrm{mM})$-high $\mathrm{Mg}^{2+}(8 \mathrm{mM})$ medium. The fold-increase was calculated as the ratio of $m$ gambierol / $m$ control values; 4-6 junctions were sampled before and $20 \mathrm{~min}$ after gambierol or 3,4-DAP-treatment; 2-4 different muscles were used for each toxin or drug concentration. 

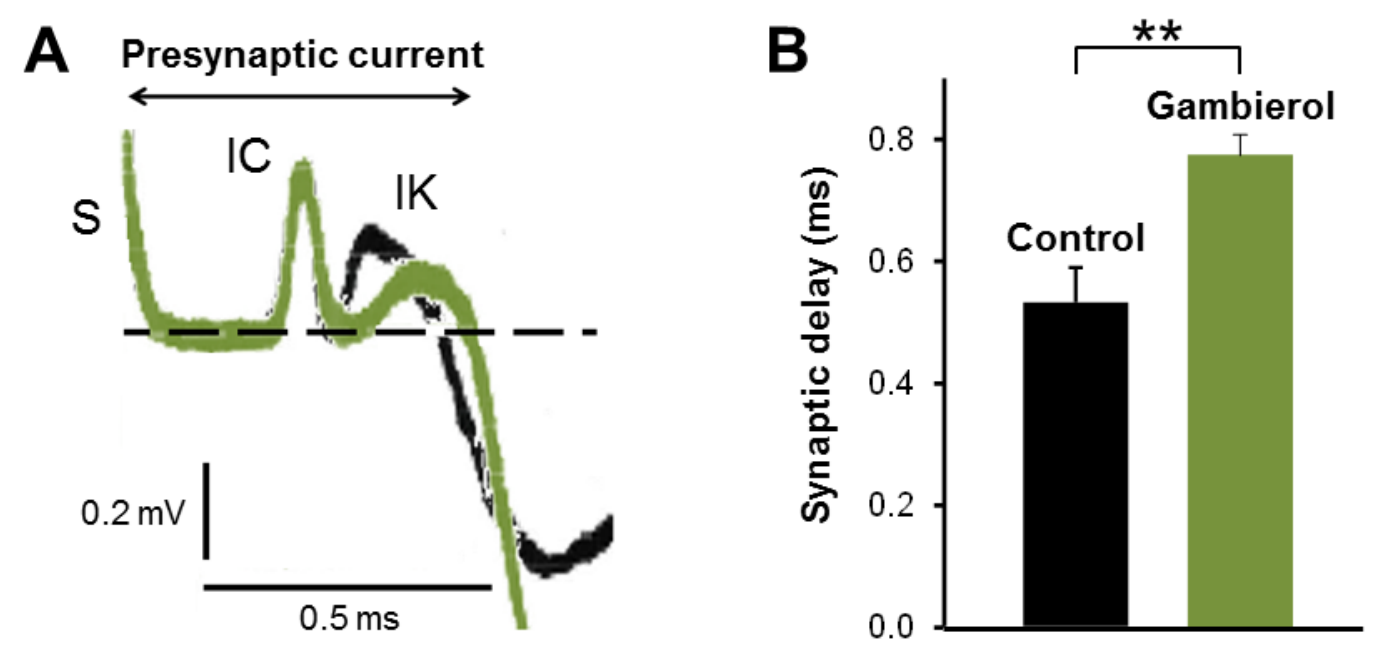

Figure 4. (A) Superimposed traces of focally recorded currents at a single neuromuscular junction of the mouse levator auris longus muscle, before (black trace) and $20 \mathrm{~min}$ after the addition of $2 \mathrm{nM}$ gambierol to the standard Krebs-Ringer solution containing $3.5 \mu \mathrm{M}$ dtubocurarine (green trace). "S" designates the nerve stimulus artefact; "IC" relates to the transient capacity current; "IK" shows the fast $\mathrm{K}^{+}$current that is partially blocked by gambierol, the postsynaptic inward currents having been truncated. Each trace is the average of 16 focal current recordings. Vertical calibration is in $\mathrm{mV}$, due to the unknown resistance between the recording microelectrode and the nerve terminal membrane. (B) Graphs showing the significant increase in the synaptic delay (**: $P=0.006$ ) at frog neuromuscular junctions treated for 50 min with $20 \mathrm{nM}$ gambierol (green column), when compared to control. 


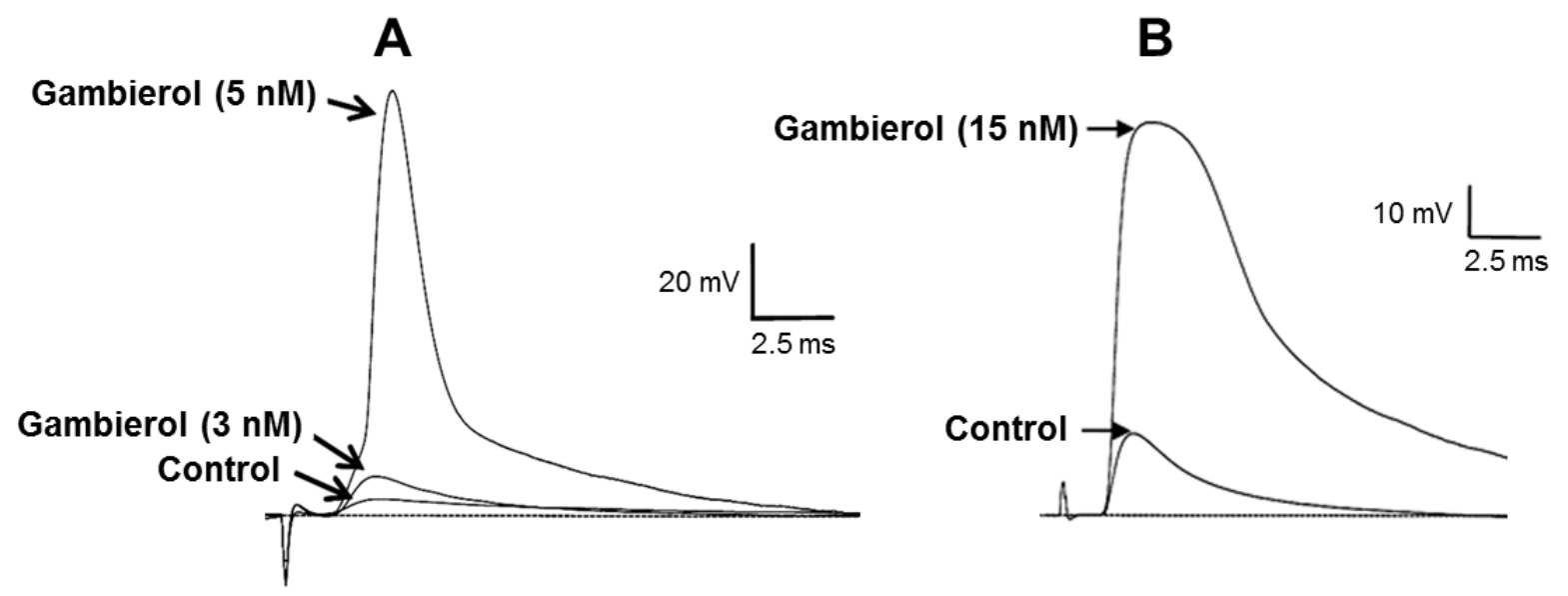

Figure 5. Gambierol reversed the post-synaptic block produced by d-tubocurarine (A), and produced full-sized EPPs (B). (A) Gambierol (2 and $5 \mathrm{nM}$ ) addition to the standard medium containing $5 \mu \mathrm{M}$ d-tubocurarine increased the amplitude, so that an EPP reached the threshold potential and triggered an action potential in the muscle fiber. (B) Increase in EPP amplitude by gambierol $(15 \mathrm{nM})$ in a neuromuscular preparation in which voltage-gated muscle $\mathrm{Na}^{+}$channels have been blocked by $\mu$-conotoxin GIIIB. Under this condition, EPPs were recorded in the absence of muscle action potentials. In (A) and (B), different frog cutaneous pectoris nerve-muscle preparation were used, in which excitation was uncoupled from contraction by pre-treatment with formamide. Resting membrane potential during measurements was $-80 \mathrm{mV}$ in $\mathrm{A}$ and $\mathrm{B}$. 

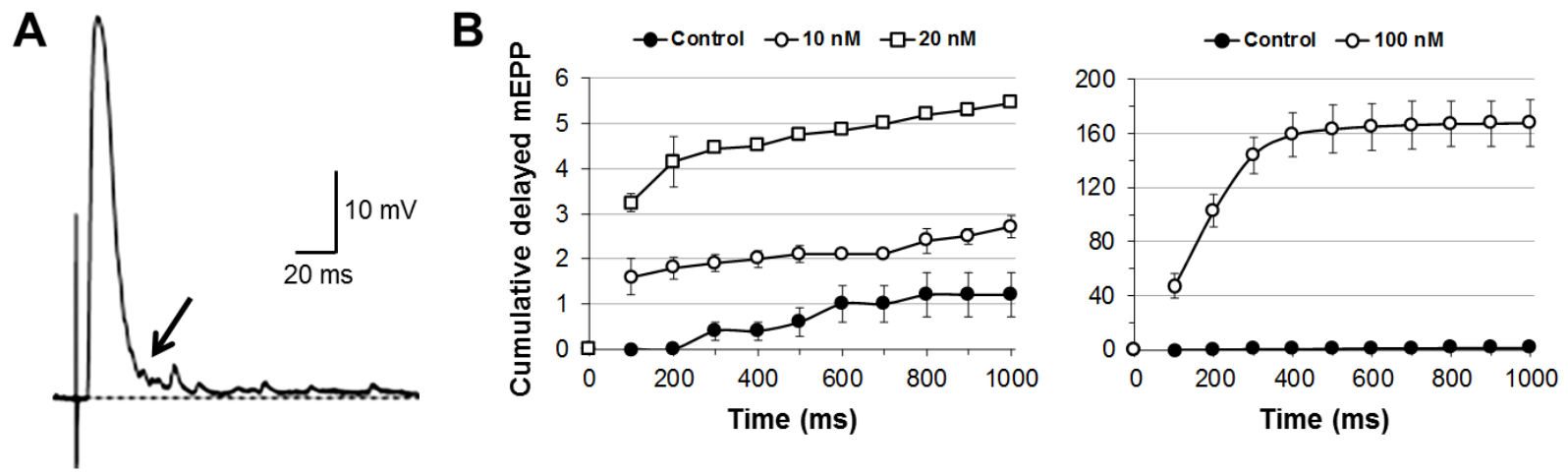

Figure 6. Gambierol increased the mEPP frequency that follows an EPP in mouse and frog neuromuscular junctions treated with $\mu$ - conotoxin GIIIB. (A) Example of an EPP evoked by nerve stimulation in a mouse hemidiaphragm junction during the action of $2 \mathrm{nM}$ gambierol. Note the presence of mEPPs in the falling phase of the EPP. Resting membrane potential was $-70 \mathrm{mV}$. (B) The graphs show examples of cumulative plots of delayed releases per stimulus as a function of time, under control conditions and with gambierol (10, 20 and $100 \mathrm{nM}$ ) in frog junctions. Nerve stimulation was $1 \mathrm{~Hz}$. Number of stimuli delivered to the motor nerve was the same under control conditions, and in the presence of gambierol. The error bars \pm show the $95 \%$ confidence limits; Data obtained from $n=3$ and $n=9$ from control and treated junctions respectively, from 3 different frog cutaneous pectoris preparations. 

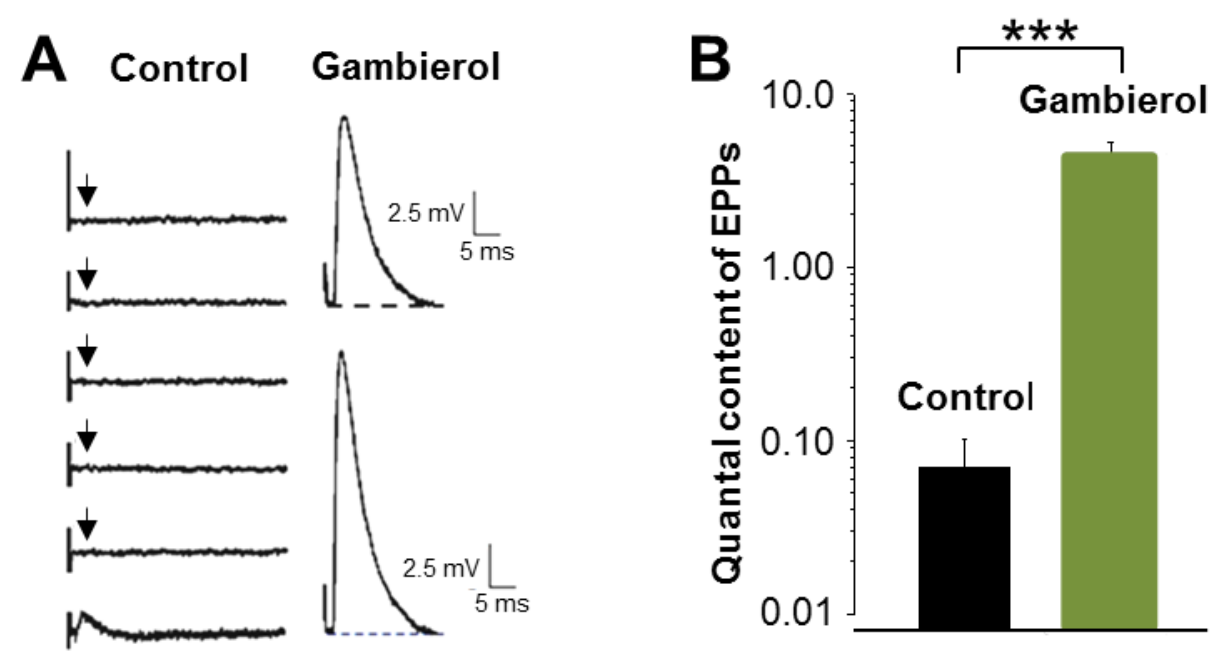

Figure 7. Gambierol increases stimulus-evoked quantal transmitter release in BoNT/A-treated junctions. Typical intracellular recordings performed ex vivo in an EDL muscle treated $72 \mathrm{~h}$ before with a single BoNT/A injection. (A) Note the important number of failures of release upon nerve stimulation (indicated by arrows) and the monoquantal EPP in the BoNT/A-treated junction (Control), and example of large amplitude EPPs recorded during the action of $15 \mathrm{nM}$ gambierol on the same junction. Resting membrane potential during recordings $-68.5 \mathrm{mV}$. (B) Mean quantal content of EPPs in BoNT/A-treated junctions, before and after the action of gambierol $(15 \mathrm{nM})$. Data obtained from 8 different junctions from 4 different BoNT/A-treated EDL muscles. Note the significant increase in the mean quantal content of EPPs $(* * *: P=$ 0.0002) after the action of gambierol, when compared to control. 


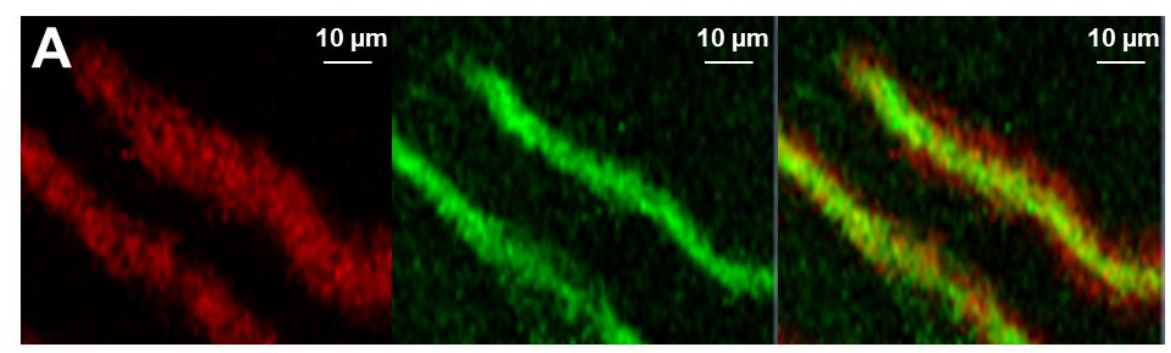

$\alpha$-BgTx-Alexa-594

Fluo3/AM

Merge
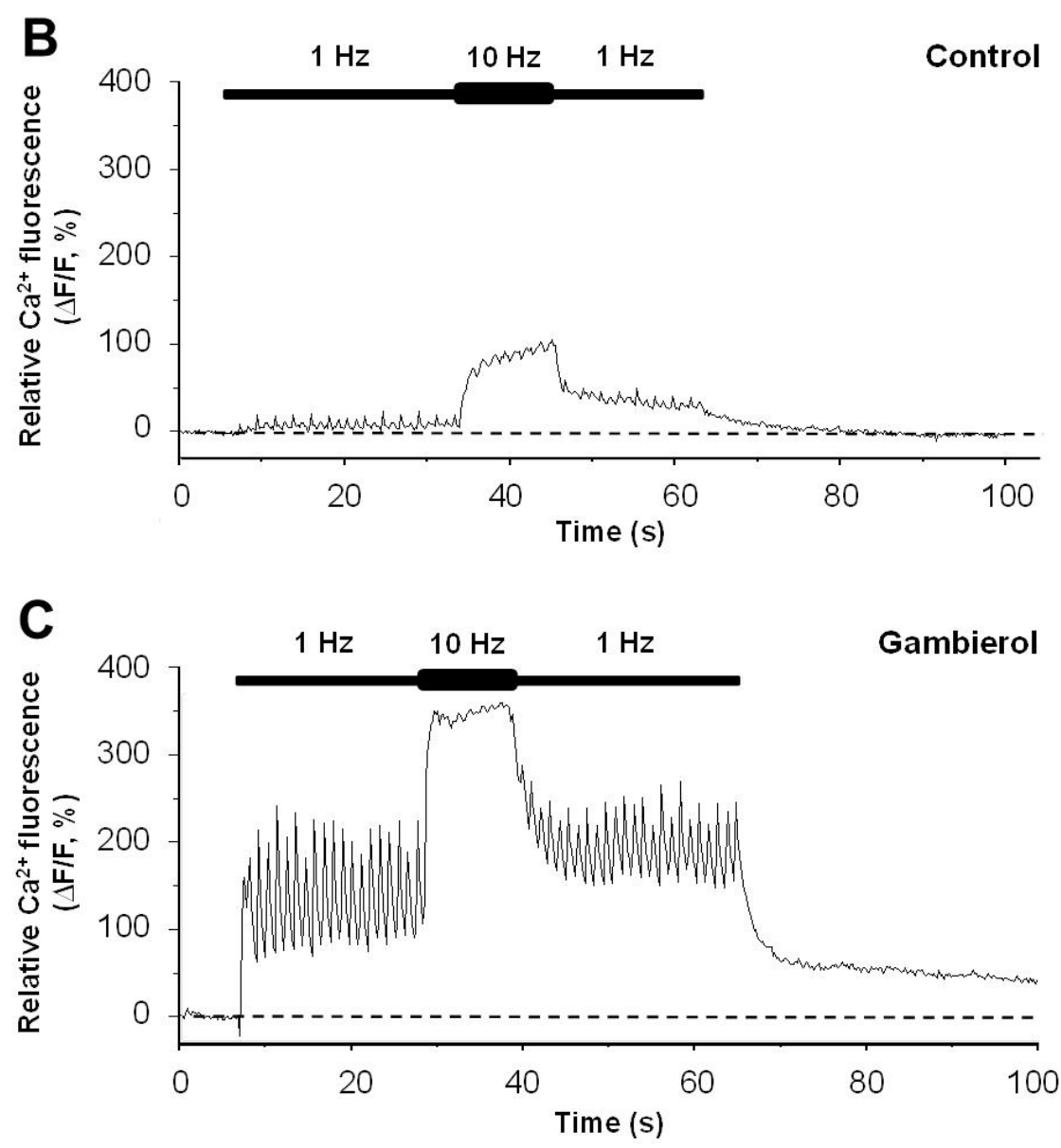

Figure 8. Confocal images showing part of a frog neuromuscular junction of the cutaneous pectoris muscle in which nAChRs have been stained with fluorescent $\alpha$-BgTx, the motor nerve terminal branches loaded with fluo-3/AM (during nerve stimulation) and a merged image (A). Calcium signals in the motor nerve terminals stimulated continuously at 1,10 and $1 \mathrm{~Hz}$ before (B), and after $50 \mathrm{nM}$ gambierol treatment (C). Data in B and C are from the same junction and from a muscle in which excitation-contraction has been uncoupled by formamide pretreatment. Note in (B) the relative tiny $\mathrm{Ca}^{2+}$ fluorescence signals recorded under control conditions, and the increase in $\mathrm{Ca}^{2+}$ fluorescence transients in the presence of gambierol (C). Note also in the presence of gambierol the slow decay of basal fluorescence levels after stopping stimulation (see text for details). 


\section{Supplementary Material videos}

Movie S1. "Molgó et al_Ca Signal-Control" fỉle

Fluorescent signals in the branches of a frog motor nerve terminal loaded with fluo-3/AM showing $\mathrm{Ca}^{2+}$ signals following continuous nerve stimulation at 1,10 and $1 \mathrm{~Hz}$ under control conditions (for details see Fig. 8B).

Movie S2. "Molgó et al_Ca Signal-Gambierol" file

Fluorescent signals in branches of a frog motor nerve terminal loaded with fluo-3/AM showing $\mathrm{Ca}^{2+}$ signals following continuous nerve stimulation at 1,10 and $1 \mathrm{~Hz}$ in the presence of $50 \mathrm{nM}$ gambierol (for details see Fig. 8C). 